\title{
Powder diffraction of yellow and red natural earths from Lessini Mountains in NE Italy
}

\author{
Giovanni Cavallo, ${ }^{1,2, a)}$ Maria Pia Riccardi, ${ }^{1}$ and Roberto Zorzin ${ }^{3}$ \\ ${ }^{I}$ Department of Earth and Environmental Sciences, University of Pavia, via Ferrata 1, 27100 Pavia, Italy \\ ${ }^{2}$ Institute of Materials and Constructions, University of Applied Sciences and Arts - Supsi, Campus Trevano, 6952 \\ Canobbio, Switzerland \\ ${ }^{3}$ Civic Museum of Natural History, Lungadige Porta Vittoria, 9, 37129 Verona, Italy
}

(Received 1 November 2014; accepted 13 December 2014)

\begin{abstract}
A first attempt to differentiate goethite- and hematite-based natural materials, used for several purposes during the Late Palaeolithic in the Lessini Mountains (Italy), is here proposed. All raw materials were collected from known geological sites within a distance of about $20 \mathrm{~km}$ from archaeological excavations (Tagliente and Fumane caves) where ochre fragments were found. X-ray powder diffraction allowed the mineralogical composition of samples collected from carbonate and volcanic geological host and parent rocks to be inferred; in addition, a preliminary distinction based on the different mineral assemblages, on the presence of distinctive mineral phases and on the degree of crystallinity of some compounds such as hematite, became possible. The acquired data thus represent a sort of preliminary inventory for provenance studies on archaeological samples originating in the same region, for which ancillary micro-analytical and geochemical techniques are planned. (C) 2015 International Centre for Diffraction Data. [doi:10.1017/S0885715614001407]
\end{abstract}

Key words: goethite, hematite, archaeological ochre, Lessini Mountains, Tagliente shelter, Fumane cave

\section{INTRODUCTION}

Red and yellow earths are natural iron oxides (mostly hematite, $\alpha-\mathrm{Fe}_{2} \mathrm{O}_{3}$ ) and oxy-hydroxides (mostly goethite, $\alpha$-FeOOH) generally associated with variable amounts of other minerals, widely used since prehistory for several purposes.

In archaeological sciences, the term "ochre" is generally accepted to designate natural iron-based materials even if they include a large variety of geomaterials displaying different mineralogical compositions, and markedly distinct textural and microstructural features (Dayet et al., 2013). To avoid confusion, in this contribution, the more general term earths will be used, indicating natural materials containing prevalently iron oxides and/or hydroxides associated with other compounds, the mineralogical and chemical compositions of which reflect the geological processes that conditioned and determined their formations.

Owing to their extraordinary hiding power, tinting strength, excellent permanence, and good compatibility with other organic and inorganic compounds (Helwig, 2007), and of their easy availability in many geological environments, both yellow and red natural earths were used worldwide for decoration of Palaeolithic caves (Delamare and Guineau, 2000), and at a later stage, also during Roman (Béarat, 1996) and Medieval times (Cavallo et al., 2012). In addition, the technology to convert yellow earths into red ones by heating is well documented as a common practice (Pomiès et al., 1998; Pomiès and Menu, 1999; Gialanella et al., 2011;

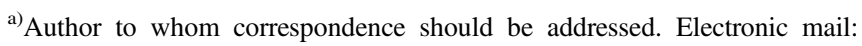
giovanni.cavallo01@ateneopv.it
}

Salomon et al., 2012). Red ochre was likely employed for utilitarian applications such as skin protection and pharmacology, for tanning hides (Henshilwood et al., 2009) or for compound-adhesive manufacture (Wadley, 2010), as drying and abrasive agents (Dayet et al., 2013), or for symbolic and ritual purposes (Hovers et al., 2003).

Lessini Mountains in Western Veneto, NE Italy, are well known for palaeokarst interior deposits rich in yellow earths (Zorzin et al., 1995). Despite the large availability and the extensive exploitation for pigment production, preliminary analytical investigations were recently initiated; accordingly, in order to understand the main distinctive compositional and textural characteristics useful for provenance studies in archaeological contexts within the same region (Cavallo and Zorzin, 2008, 2014), spot samples in a few mines were duly collected. In particular, an extensive survey was organized in the province of Verona for the collection of geological samples (Cavallo et al., 2014), the characterization of which is the first step for provenance studies of archaeological yellow and red ochres excavated in two important Palaeolithic sites known as Grotta di Fumane (Broglio et al., 2009; Peresani et al., 2013) and Riparo Tagliente (Fontana et al., 2009).

The identification of the area and samples collection (Figure 1) was based on a detailed survey around the two archaeological sites and within a distance of about $20 \mathrm{~km}$. For local and sub-local sources, the available historic and archival documentations, dating back to the late 19th $c$. (Nicolis, 1898) and mid-20th $c$. (Federici, 1948) were consulted. In addition, materials collected from the palaeokarst caves having hazardous or impossible access for prehistoric people were also included in order to have access to a wider database. 


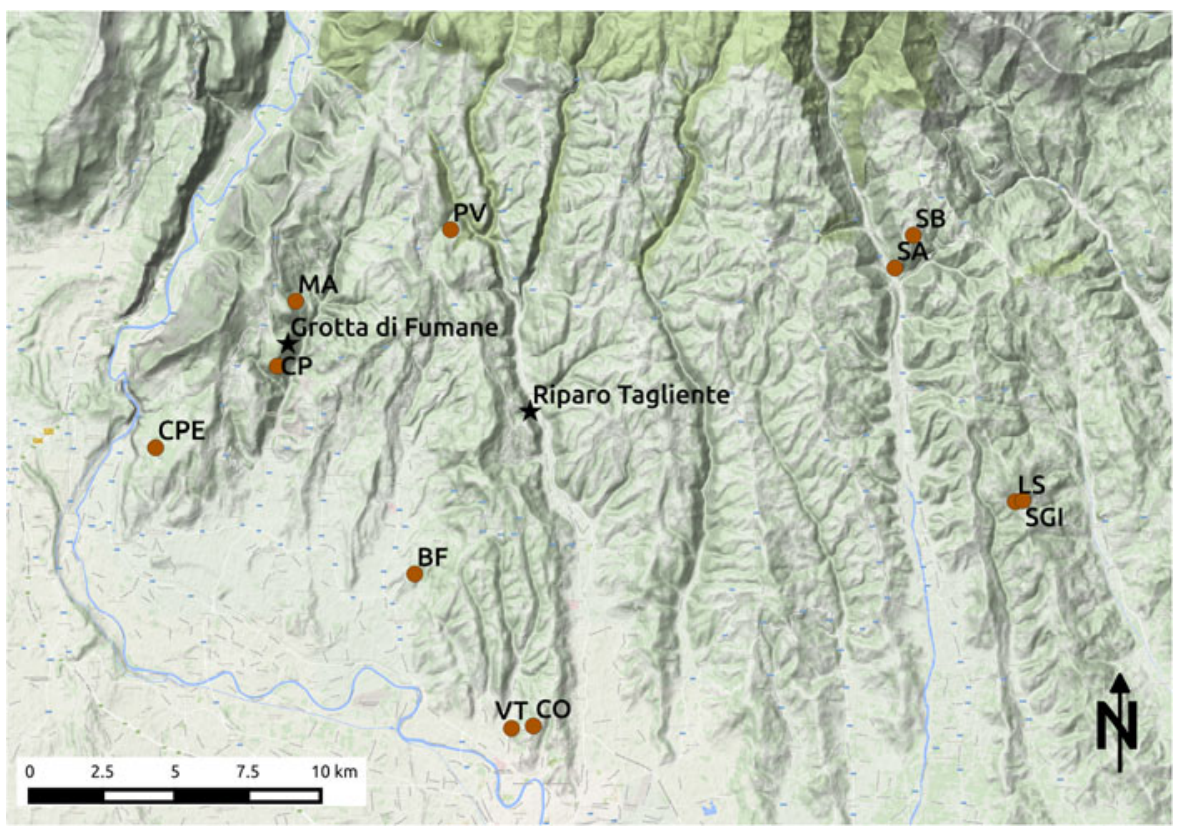

Figure 1. (Color online) Location of the collected yellow and red natural Fe-based earths (brown circles) and of the archaeological sites (black stars). Base map (O2014 Google.

The mineralogical characterization by means of X-ray powder diffraction (XRD) is an important task as it allows us to make a preliminary distinction of yellow and red earths characteristic mineral assemblages which depend on the processes leading to their formation (source rock, mineral weathering, transport mechanism, and accumulation). Co-existing mineral phases can be specific of particular geological environments, helping in narrowing down the possible provenance area (Hradil et al., 2003).

\section{MATERIALS AND METHODS}

The detailed description of all collected samples is reported in Table I. The color notation is reported according to Munsell Soil Color Charts (1975) and corresponds to the bulk color of the analysed sample (in the form of powders). Representative samples of yellow earths were collected from palaeokarst caves opening in Eocene limestones (formation known as Marne di Priabona), located close to the city of Verona; these mines are called via Tirapelle cave, locality Valdonega (VT-P samples from the main corridor, near the entrance; VTf samples from the layered deposit at the end of the principal corridor; TP samples from the principal corridor, VT-S samples from the layered sequence at the end of the branch called squalo, shark), and Colombare cave (samples labelled CO: stations A, C moving from the artificial shaft $18 \mathrm{~m}$ deep). Other samples were collected from caves in the Early Jurassic Calcari Grigi dolomitizzati (Dolomitized Grey Limestones), part of the Complesso Dolomitico Indifferenziato (Undifferentiated Dolomite Complex); in particular, samples were taken from the palaeokarst cave at Selva di Progno, locality San Bortolo delle Montagne (samples labelled SB are representatives of the $1.5 \mathrm{~m}$ thick profile of the outcrop), the palaeokarts cave in Val d'Illasi, locality Sant'Andrea (SA samples are representatives of $1.2 \mathrm{~m}$ thick profile), $\mathrm{Ca}$ ' del Paver, Fumane (samples labelled CP). Samples from Oolite of San Vigilio and Rosso Ammonitico Veronese (Late Jurassic) were collected at the palaeokarst system Ponte di Veja, Sant'Anna d'Alfaedo (samples labelled as PV-A, PV-G, PV-D/E where A, G, and D/E correspond to the caves as reported in Zorzin et al., 1995), Ca' de la Pela paleaokarts cave (Oolite di San Vigilio) located at $S$. Ambrogio di Valpolicella (CPE samples correspond to the homogeneous layers of the laminated sequence) and Fumane, locality Manune (MA), corresponding to the A, B, and $\mathrm{C}$ stations. Yellow earths are also associated with volcanic rocks (Eocene basalts) at San Giovanni Ilarione, locality Viale (SGI); Eocene volcaniclastic terrains in stratigraphic continuity with Eocene limestones at Buso del Ferro, Negrar municipality (BF samples collected from the main gallery identified as A and the upper level of the main gallery called C) host yellow materials (originally this was an artificial mining site where goethite and pyrolusite were exploited).

In general, the majority of the samples display a layered structure due to the major-minor amount of some mineral species and reflecting the variability of the weathering, transport, and depositional processes (Figure 2). However, in some cases (SGI, SA, MA, and CP), no layered structures were detected (Figure 3).

X-Ray powder diffraction (XRPD) was carried out on randomly oriented samples deposited in the hollow of an $\mathrm{Si}$ monocrystal zero-background plate, supplied by Assing spa, Monterotondo, Italy. A Bruker D8 Advance system, operating in $\theta: \theta$ mode was used; generator setting $40 \mathrm{kV}, 40 \mathrm{~mA}, \mathrm{Cu}$ anode $\left(\mathrm{Cu} K \alpha=1.5418 \AA\right.$ ), Ni filter, $2 \theta$ range $5-55^{\circ}$, step size $0.02^{\circ}$, scan speed $0.5^{\circ} \mathrm{min}^{-1}$. Because of the large fluorescence caused by Fe-rich materials, the setting of the Lynxeye PSD detector was adjusted to the best of its performances by lowering the acceptance window, at the expense of some intensity loss, but significantly improving the $\mathrm{S} / \mathrm{N}$ ratio.

\section{RESULTS}

The mineral assemblages of all collected samples, listed in order of relative abundance, are reported in Table I. The majority of these samples are yellow earths, associated with 
TABLE I. Synoptic description of the collected yellow and red earth samples. Mineral phases are listed in order of abundance.

\begin{tabular}{|c|c|c|c|c|}
\hline ID & Color & Macroscopic description & Geology & Mineral phases \\
\hline VT-P-02 & 10YR 6/8 & $\begin{array}{l}\text { Yellow material not coherent with white carbonate nodules } \\
\text { and a brown very hard sub-level of a few mm thick }\end{array}$ & $\begin{array}{l}\text { Eocene limestones - Marne di } \\
\text { Priabona Formation (Priabona } \\
\text { Marls) }\end{array}$ & Qtz, Gt, Cal \\
\hline VTf-01 & $10 Y R 5 / 8$ & $\begin{array}{l}\text { Dark level in the lower part of the layered sequence, end } \\
\text { of the main corridor of the mine }\end{array}$ & & $\mathbf{G t}, Q z$ \\
\hline TP-1 & 10YR 5/8 & Yellow earth with carbonate inclusions & & Qz, Gt, Cal, Dol \\
\hline TP-2 & 10YR 5/8 & Friable brown earth with calcareous sandy grains & & $\mathbf{G t}, \overline{\mathrm{Cal}}, \overline{\mathrm{Qz}}$ \\
\hline TP-3 & $10 \mathrm{YR} 8 / 8$ & Homogeneous and friable yellow-brown earth & & Ank, Qz Gt, Ms \\
\hline TP-4 & $7.5 Y R 5 / 8$ & Yellow-brown silty earth & & Qz, $\underline{\mathrm{Gnt}}, \underline{\mathrm{Dol}}, \mathrm{Ms}$ \\
\hline VT-S-01_y & $10 \mathrm{YR} 8 / 8$ & Yellow level of the sequence, homogeneous & & $\begin{array}{l}\text { Ank, Gt, }, \underline{\mathrm{Qz}}, \mathrm{Ms}, \\
\quad \mathrm{K} \ln , \mathrm{Cal}\end{array}$ \\
\hline VT-S-02-3Rf & $7.5 \mathrm{YR} 6 / 8$ & Yellow level passing to brown color & & Ank, Gt, Qz, Hem \\
\hline VT-S-02-3Rc & $5 Y R 6 / 8$ & Red level exhibiting carbonate crystals & & $\begin{array}{l}\text { Ank, Qz, Ms, Gt } \\
\quad K \ln , \text { Hem }\end{array}$ \\
\hline VT-S-08 & $7.5 \mathrm{YR} 6 / 8$ & $\begin{array}{l}\text { Yellow level with white carbonate spots, friable. Red } \\
\text { microlaminations are visible as well }\end{array}$ & & Ank, Gt, Qz \\
\hline VT-S-09 & $10 \mathrm{YR} 6 / 8$ & $\begin{array}{l}\text { Yellow level, homogeneous and compact. Presence of white } \\
\text { carbonate spots }\end{array}$ & & Ank, Qz, Gt, Cal \\
\hline VT-S-10 & 10YR 6/8 & Yellow level, homogeneous and compact & & Ank, Gt, Cal, Qz \\
\hline PV-A-01a & $10 \mathrm{YR} 5 / 8$ & Homogeneous and compact material & $\begin{array}{l}\text { Oolite di San Vigilio and Rosso } \\
\text { Ammonitico Veronese (Late } \\
\text { Jurassic) }\end{array}$ & $\mathbf{G t}, \mathrm{Cal}, \mathrm{Qz}$ \\
\hline $\mathrm{PV}-\mathrm{A}-02$ & $10 Y R 7 / 8$ & $\begin{array}{l}\text { Homogeneous and compact material. The presence of } \\
\text { carbonates level is evident }\end{array}$ & & Cal, Gt, Qz \\
\hline PV-D/E-01 & $10 Y R 6 / 8$ & $\begin{array}{l}\text { Upper part of the sequence. Homogeneous material with } \\
\text { brown laminations disposed along longitudinal planes; } \\
\text { sometimes moderate waves are visible }\end{array}$ & & Gt, Cal, Qz \\
\hline PV-D/E-02a & $10 Y R 5 / 8$ & $\begin{array}{l}\text { Lower part of the sequence. Yellow level with brown thin } \\
\text { laminations and quartz crystals disposed along longitudinal planes }\end{array}$ & & Gt, Qz, Cal \\
\hline PV-D/E-02b & $10 Y R 5 / 8$ & $\begin{array}{l}\text { Lower part of the sequence. Brown level with yellow thin } \\
\text { laminations and carbonate crystals disposed along longitudinal } \\
\text { planes }\end{array}$ & & $\mathbf{Q z}, \underline{\mathrm{Gt}}, \mathrm{Cal}$ \\
\hline PV-G-01 & 10YR 7/8 & Homogeneous and compact material with very sharp edges & & Qz, Gt \\
\hline PV-G-01a & 10YR 7/8 & Homogeneous and compact material, very hard & & $\mathbf{Q z}, \mathrm{Gt}$ \\
\hline PV-G-01b & 10YR 7/8 & Homogeneous and compact material, very hard & & Qz, Gt \\
\hline SB-01 & $7.5 Y R 5 / 8$ & Homogeneous and compact yellow-brown material & $\begin{array}{l}\text { Early Jurassic Calcari Grigi } \\
\text { dolomitizzati (dolomitized Grey } \\
\text { Limestones) }\end{array}$ & Ank, Gt, Cal \\
\hline SB-02 & 10YR 7/8 & Homogeneous and compact yellow-brown material & & Ank, Gt, Cal \\
\hline SB-03 & 10YR 6/8 & Homogeneous and compact yellow-brown material & & Ank, Gt, Cal \\
\hline SB-05 & 10YR 6/8 & Homogeneous and compact yellow- brown material & & Ank, Gt, Cal \\
\hline SA-A1 & 10YR 6/8 & Yellow earth, very well cemented exhibiting rare red spots & $\begin{array}{l}\text { Early Jurassic Calcari Grigi } \\
\text { dolomitizzati (dolomitized Grey } \\
\text { Limestones) }\end{array}$ & Dol, $\underline{\mathrm{Gt}}$ \\
\hline SA-A2 & $10 \mathrm{R} 4 / 8$ & Red earth, very well cemented, exhibiting rare yellow spots & & Hem, Ank \\
\hline SA-A3 & $10 \mathrm{R} 4 / 8$ & Cemented and homogeneous red earth & & Hem, Ank \\
\hline SA-A4 & $10 Y R 7 / 8$ & $\begin{array}{l}\text { Yellow earth, very well cemented, exhibiting laminations } \\
<1 \mathrm{~mm} \text { thick, purple in color }\end{array}$ & & Gt, Ank \\
\hline $\mathrm{SA}-\mathrm{B} 0$ & $10 Y R 7 / 8$ & $\begin{array}{l}\text { Yellow earth, very well cemented, homogeneous, exhibiting } \\
\text { purple laminations, thickness a few mm }\end{array}$ & & Ank, Gt \\
\hline CPE-A0 & $7.5 Y R 5 / 6$ & $\begin{array}{l}\text { Yellow-brown homogeneous and compact material; white } \\
\text { longitudinal micro-laminations and brown (rare) are present }\end{array}$ & Oolite di San Vigilio (Late Jurassic) & Ank, Gt \\
\hline CPE-B0 & $7.5 Y R 5 / 8$ & $\begin{array}{l}\text { Brown homogeneous and compact material exhibiting dark-brown } \\
\text { microlaminations }\end{array}$ & & Cal, Gt, Ank \\
\hline $\mathrm{CPE}-\mathrm{CO}$ & $7.5 Y R 8 / 6$ & $\begin{array}{l}\text { Yellow homogeneous and compact material exhibiting white } \\
\text { carbonate inclusions }\end{array}$ & & Ank, $\mathrm{Cal}, \mathrm{Gt}$ \\
\hline CPE-D0 & $7.5 \mathrm{YR} 5 / 6$ & Brown homogeneous and compact material & & Gt, Ank, Cal \\
\hline BF-A1 & $2.5 \mathrm{Y} 7 / 4$ & Yellow earth from the vault at the end of the mail gallery & $\begin{array}{l}\text { Eocene volcanoclastic terrains (foot } \\
\text { wall) and Eocene Limestones }\end{array}$ & Cal, Gt \\
\hline $\mathrm{BF}-\mathrm{A} 2$ & $10 \mathrm{YR} 5 / 8$ & Yellow earth from the deposit at the end of the mail gallery & & Gt, Cal, Qz \\
\hline $\mathrm{BF}-\mathrm{A} 3$ & $2.5 \mathrm{Y} 8 / 2$ & $\begin{array}{l}\text { Yellow earths associated with volcanic terrains from the } \\
\text { terminal section of the main gallery }\end{array}$ & & $\begin{array}{l}\text { Gt, Kln, Mnt, } \\
\text { Pyrolusite }\end{array}$ \\
\hline $\mathrm{BF}-\mathrm{C} 1$ & $10 Y R 6 / 6$ & Yellow earth with green-grey millimetre laminae intercalations & & Cal, Gt, $Q z$ \\
\hline
\end{tabular}

Continued 


\begin{tabular}{|c|c|c|c|c|}
\hline ID & Color & Macroscopic description & Geology & Mineral phases \\
\hline $\mathrm{CO}-1 \mathrm{~A}$ & 10YR 6/8 & Yellow earth with lighter sub-levels and carbonate crystals & $\begin{array}{l}\text { Eocene limestones - Marne di } \\
\text { Priabona Formation (Priabona } \\
\text { Marls) }\end{array}$ & Qz, Dol(?), Gt, Ms \\
\hline $\mathrm{CO}-2 \mathrm{~A}$ & 10YR 7/8 & Yellow earth with lighter sub-levels and carbonate crystals & & $\begin{array}{l}\text { Qz, Ank, Gt, Ms, } \\
\quad \text { Cal, Kln }\end{array}$ \\
\hline $\mathrm{CO}-3 \mathrm{~A}$ & 10YR 6/8 & Yellow earth with evident brown lamina a few $\mathrm{mm}$ thick & & Qz, Ank, Gt, Ms \\
\hline CO-4A_Y & 10YR 8/6 & Homogeneous yellow-orange earth & & $\begin{array}{l}\text { Qz, } \overline{\mathbf{A n k}}, \mathrm{Cal}, \mathrm{Ms}, \\
\quad \text { Gt, Kln }\end{array}$ \\
\hline CO-7A & 10YR 5/8 & Yellow-brown earth with evident micro-laminations & & Ank, Gt \\
\hline $\mathrm{CO}-1 \mathrm{C}$ & 10YR 7/6 & Homogeneous pale-yellow earth & & $\begin{array}{l}\mathrm{Qz}, \underline{\mathrm{Ank}}, \mathrm{Ms}, \mathrm{Cal}, \\
G \overline{t, K l n}\end{array}$ \\
\hline $\mathrm{CO}-2 \mathrm{C}$ & 10YR 6/8 & Yellow earth with brown layers about $10 \mathrm{~mm}$ thick & & Ank, Gt, Ms, Qz \\
\hline CO-3C_Y & 10YR 6/6 & Yellow and yellow-orange earths mixed together & & $\underset{G z}{\mathbf{Q z}}, \underline{\overline{n k}}, \mathrm{Ms}, K l n$, \\
\hline CP-1a & 7.5YR $8 / 4$ & Yellow material associated with the dolomitized Grey Limestones & $\begin{array}{l}\text { Early Jurassic Calcari Grigi } \\
\text { dolomitizzati (Dolomitized Grey } \\
\text { Limestones) }\end{array}$ & Ank \\
\hline $\mathrm{CP}-2 \mathrm{a}$ & $7.5 \mathrm{YR} 8 / 4$ & Yellow material associated with the dolomitized Grey Limestones & & Ank, Cal \\
\hline MA-A-01 & $5 Y R 7 / 6$ & Red horizon associated with Oolite di San Vigilio & Oolite di San Vigilio (Late Jurassic) & Cal, Ank $Q z$ \\
\hline MA-B-01 & $5 Y R 7 / 4$ & Red horizon associated with Oolite di San Vigilio & & Cal, $\overline{\mathrm{Ank}}$ \\
\hline MA-C-01 & $2.5 \mathrm{YR} 6 / 8$ & Red horizon associated with Oolite di San Vigilio & & Ank \\
\hline SGI-A-01 & $2.5 \mathrm{YR} 4 / 6$ & Red earth associated with basalt rocks & Eocene basalts & $\begin{array}{l}\text { Mnt, }, \text { Hem, Ant, } \\
\text { Kln, Gt }\end{array}$ \\
\hline SGI-A-02 & 7.5YR 5/6 & Yellow earth associated with basalt rocks & & 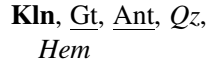 \\
\hline
\end{tabular}

VT-P, VTf, TP, VT-S (samples from the paleokarst mine in via Tirapelle, locality Valdonega, Verona; VT-P samples from the main corridor, near the entrance; VTf samples from the layered deposit at the end of the principal corridor; TP samples from the principal corridor, VT-S samples from the layered sequence at the end of the branch called squalo, shark). VTf, TP, and VT-S samples correspond to individual layers of the collected layered sequence.

PV-A, PV-G, PV-D/E (samples from the palaeokarst system called Ponte di Veja, Sant'Anna d'Alfaedo, Verona; A, G, D/E correspond to the caves as reported in Zorzin et al., 2005).

SB (samples from the outcropping area of the palaeokarst cave at Selva di Progno, locality San Bortolo delle Montagne, Verona). Collected samples are representative of $1.5 \mathrm{~m}$ thick profile of the outcrop.

SA (samples from the palaeokarts cave in Val d'Illasi, locality Sant'Andrea). Collected samples are representative of $1.2 \mathrm{~m}$ thick profile.

CPE (samples from the paleaokarts cave located at S. Ambrogio di Valpolicella Municipality, locality Ca' del la Pela). Samples correspond to the homogeneous layers of the laminated sequence.

BF (samples collected from the different galleries - A: main gallery, C: upper level of the main gallery - of the Fe-Mn abandoned mine located at Negrar municipality).

CO (samples collected from the stations A, C moving from the artificial shaft $18 \mathrm{~m}$ deep of the Colombare palaeokarst cave on the hill around Verona).

CP (samples collected from the dolomitized Grey Limestones outcrop at Fumane, locality $\mathrm{Ca}$ ' del Paver).

MA (samples collected from three stations A, B, C, located at Fumane, locality Manune).

SGI (samples collected from the Eocene basalt outcropping area at San Giovanni Ilarione, locality Viale).

Note: Mineral abbreviations as in Whitney and Evans (2010). Relative mineral abundance: $\mathbf{M}$ principal $\underline{\mathrm{M}}$ subordinate $\mathrm{M}$ accessory $M$ traces.

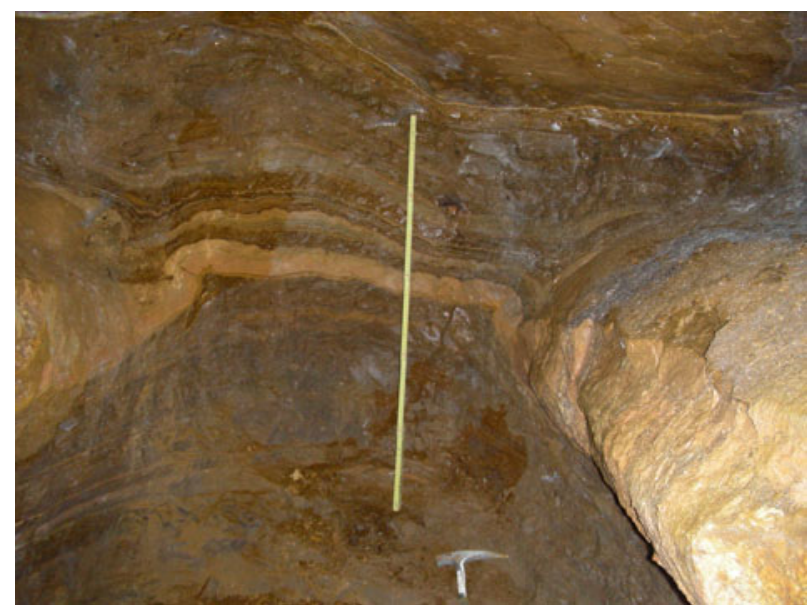

Figure 2. Layered and deformed sediments occurring in the $\mathrm{Ca}^{\prime}$ de la Pela palaeokarst cave (bar length $=1 \mathrm{~m}$ ).

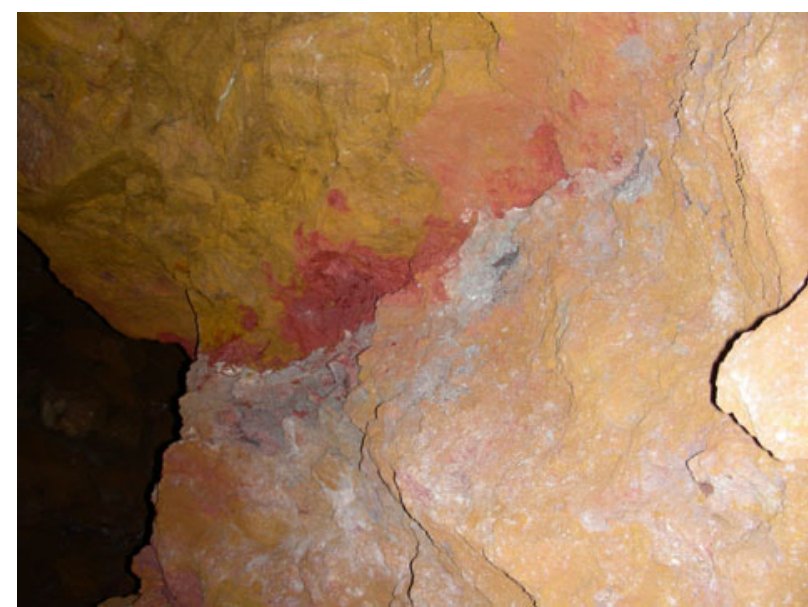

Figure 3. Massive yellow earth (upper part) with limited spots of red earth (Sant'Andrea mine). Calcari Grigi dolomitizzati are displayed in the lower part of the picture (height of the picture about $80 \mathrm{~cm}$ ). 


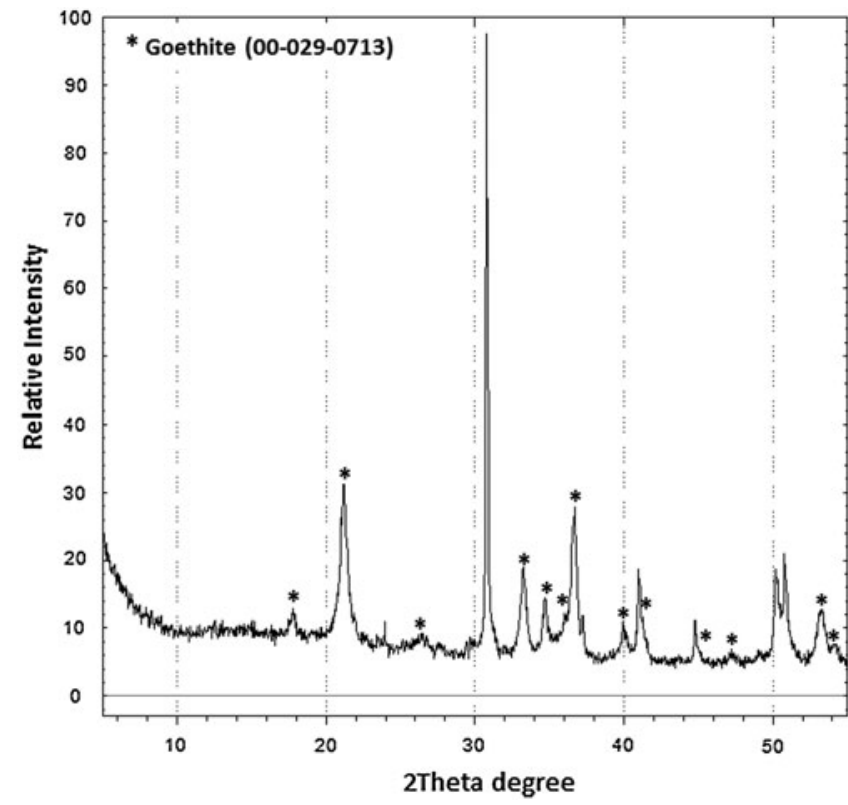

Figure 4. Poorly crystalline goethite associated with ankerite (sample CPE-A0).

carbonate rocks; on the contrary, the most extensive deposits of red earths are associated with volcanic rocks (basalts).

\section{A. Yellow earths}

The mineralogical phase imparting color to the collected yellow earths is poorly crystalline goethite (Figure 4), for which diffraction peaks [e.g. the most intense reflections at $d=4.179 \AA$ (110), $d=2.692 \AA(130)$ and $d=2.406 \AA$ (111)] are significantly broadened (three times above the welldefined quartz reflection). The different colors, varying from yellow to brown, depend on the relative amount of accompanying minerals: higher the quantity of this fraction, lighter the color. Significantly, the amount of Fe-based compounds in the sample from $\mathrm{CP}$ is negligible (quantity $<$ LOD, amorphous), the yellow hue being attribute to ankerite weathering.

Not unexpectedly, samples originating from the Calcari Grigi Dolomitizzati (CP, SA, SB) exhibit the presence of ankerite, dolomite, and calcite; the same behaviour is displayed by the CPE samples collected from the Oolite di San Vigilio formation. In addition, samples SA do not contain calcite, thus allowing a further distinction. Ankerite $\left[\mathrm{Ca}\left(\mathrm{Fe}_{x} \mathrm{Mg}_{1-x}\right)\right.$ $\left.\left(\mathrm{CO}_{3}\right)_{2}, \quad 0 \leq x \leq 0.7\right]$ is a solid solution of the $\mathrm{FeCO}_{3}-$ $\mathrm{MgCO}_{3}$ system, in which $\mathrm{Fe}^{2+}$ (partially) substitutes $\mathrm{Mg}^{2+}$ in the dolomite crystal (Chay and Navrotsky, 1996); accordingly, the composition of ankerite is not unique, as it depends on the $\mathrm{Fe}^{2+} / \mathrm{Mg}^{2+}$ molar ratio. Since the ankerite lattice parameters are known to depend on the average of $\mathrm{Fe}^{2+}$ substitution, we estimated the composition of our samples as $0.35<x<0.54$ (SB); $0.47<x<0.54$ (CP); $0.13<x<0.30$ (SA). Estimation was calculated using a calibration curve based on ankerite cell parameters reported in Chay and Navrotsky (1996).

Yellow earths from Ponte di Veja (PV) exhibit two clear and well distinguishable patterns: poorly crystalline goethite is associated with quartz and calcite in the samples coming from the caves named $\mathrm{A}$ and $\mathrm{D} / \mathrm{E}$ (PV-A and PV-D/E

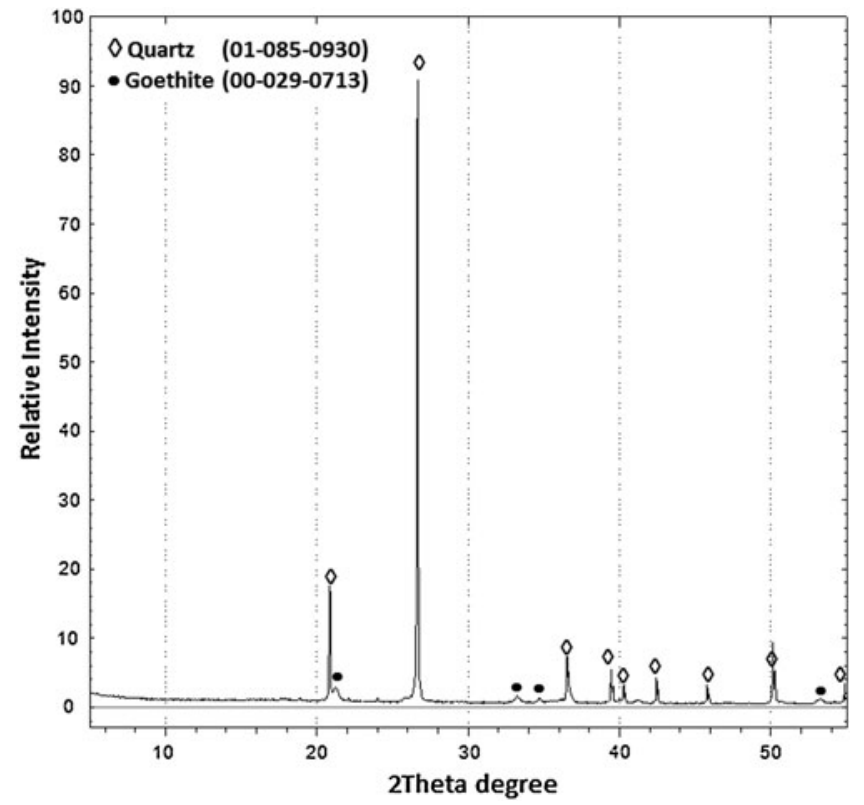

Figure 5. Mineralogical association between goethite and quartz, characteristic of samples from the Cave G at Ponte di Veja (sample PV-01a).

samples); differently, poorly crystalline goethite is associated with quartz only (Figure 5) in the samples coming from the cave G (samples PV-G).

Poorly crystalline goethite is associated with variable amounts of quartz, calcite, ankerite ( $x$ values ranging from 0.31 to 0.66 ), mica (muscovite), and clay minerals (almost exclusively kaolinite) in the samples coming from the Eocene limestones (samples VT, CO). These two groups are clearly representative of the palaeokarst caves opening within the Marne di Priabona and clearly distinguishable from the previous ones for the presence of micas and clay minerals.

The mineralogical association between goethite and accompanying minerals in the samples collected at Buso del Fero (BF) depends on the selected horizon, as Eocene limestones are in stratigraphic continuity with Eocene volcanic terrains. Samples BF-A2 and BF-C1 contain quartz, calcite, and goethite, whereas BF-A1 contains only calcite associated with goethite. Completely different is the paragenesis of the sample BF-A3 where goethite is associated with kaolinite and montmorillonite, indicating an advanced level of alteration of the volcanic terrains.

The yellow earths associated with Eocene basalts (SGI-A-02) indicate the presence of goethite associated with quartz, anatase, kaolinite, and montmorillonite. The presence of anatase in this sample represents a definite mineralogical marker as no other yellow earth samples contain Ti-oxide.

\section{B. Red earths}

Hematite is the leading mineral imparting color to the red earths. Extensive outcrops are found at San Giovanni Ilarione (SGI) in the locality called Viali or Viale and are associated with basalts. The homogeneous horizon displaying variable thickness from 0.2 to about $2 \mathrm{~m}$ was studied by Cavallo and Zorzin (2014); poorly crystalline hematite is associated with poorly crystalline kaolinite and anatase with traces of detrital quartz. A new deposit is discussed here. Poorly crystalline hematite is associated with poorly crystalline clay minerals 


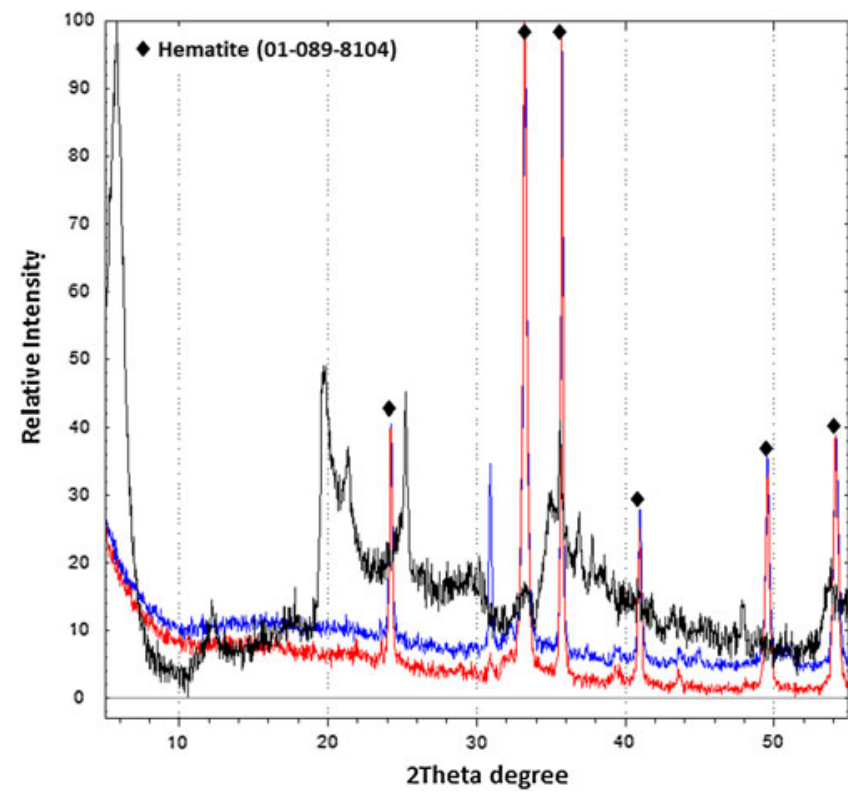

Figure 6. Comparison between well-crystallized (samples SA-A2, blue profile and SA-A3, red profile) and poorly-crystalline hematite (sample SGI-A-01, black profile). Remaining mineral phases are reported in Table I.

mainly represented by montmorillonite and, subordinately, by kaolinite. Anatase and traces of goethite are the remaining mineralogical phases.

Hematite was also found to be associated with the yellow earths collected at San Andrea mine (samples SA); in this case, hematite-rich earths are not present in an individual horizon as in San Giovanni Ilarione, but represent an irregular spot about $1 \mathrm{~m}$ wide. Except for the presence of traces of ankerite, no other minerals were detected, this fact allowing a clear distinction with the red earths from San Giovanni Ilarione. The distinction between hematite collected from the two outcrops can also be made on the basis of the degree of crystallinity as clearly visible comparing the profiles of the samples SA-A2, SA-A3, and SGI-A-01 where hematite peaks are shown (Figure 6).

Minor amounts of hematite, goethite, and kaolinite were found in association with ankerite, quartz, and muscovite in the samples coming from the "shark's gallery" in the via Tirapelle palaeokarst system. Finally, samples from Manune (MA) do not contain recognizable mineral phases associated with the red color probably due to the low amount $(<\mathrm{LOD})$ and/or amorphous.

\section{DISCUSSION}

A preliminary distinction of the analysed samples is possible based on the mineralogical association as separately reported in Tables II and III (for yellow and red earths, respectively). Tables II and III also contain information on the parent and host rocks of the collected raw materials.

Yellow earths occurring in Mesozoic formations exhibit characteristic and distinctive mineralogical associations. The most evident grouping separates quartz-free (SA, SB, CPE) and quartz-rich (PV) earths; at the moment it is very difficult to explain why large amount of quartz is associated with goethite in carbonate host formations. In addition, the presence of ankerite identifies both the dolomitized (Calcari Grigi Dolomitizzati) and the oolitic limestones (Oolite di San Vigilio). Petrographic analysis allowed the distinction of ankerite origin: in the former (SA and SB samples) ankerite is autochtonous whereas it is partially or not transformed into goethite whilst in the latter (CPE) it corresponds to secondary crystallization of $\mathrm{Fe}^{2+}$ and $\mathrm{Mg}^{2+}$ rich fluids (allochtonous). This behaviour allows the different position of the yellow earths (massive in the Calcari Grigi Dolomitizzati and layered in the Oolite di San Vigilio) to be explained.

Samples from the Eocene limestones (VT, CO), known in the geological literature as Marne di Priabona (Marls from Priabona), have a specific mineralogical association which includes quartz, calcite, ankerite, muscovite, and traces of kaolinite. This assemblage can be considered as rather distinctive, reflecting the composition of the Miocene-Oligocene terrains (sandstones, consolidated sands) which were eroded and transported into the cave. From the available observations, presently we cannot exclude the possibility that the same Eocene limestone contributed to the deposit formation.

Yellow earths which are in continuity with Eocene basalt rocks (SGI-A) exhibit the presence of kaolinite and anatase, both deriving from alteration processes affecting the mother

TABLE II. Yellow earths: characteristic mineral assemblages.

\begin{tabular}{lll}
\hline \hline \multicolumn{1}{c}{ Occurrences } & \multicolumn{1}{c}{ Geological formation } & \multicolumn{1}{c}{ Mineral assemblages } \\
\hline SA & Calcari Grigi dolomitizzati (Mesozoic) & $\mathrm{Gt}+\mathrm{Ank}$ and Gt + Dol \\
SB & & $\mathrm{Gt}+\mathrm{Ank}+\mathrm{Cal}$ \\
CPE & Oolite di San Vigilio (Mesozoic) & $\mathrm{Gt}+\mathrm{Qz}+\mathrm{Cal}$ \\
PV (caves A, D/E) & Oolite di San Vigilio and Rosso Ammonitico & $\mathrm{Gt}+\mathrm{Qz}$ \\
PV (cave G) & Veronese (Mesozoic) & $\mathrm{Gt}+\mathrm{Qz}+\mathrm{Cal}+\mathrm{Ank}+\mathrm{Ms}+\mathrm{Kln}$ \\
VT, CO & Eocene limestones (Marne di Priabona) & $\mathrm{Gt}+\mathrm{Cal}+\mathrm{Qz}$ and Gt $+\mathrm{Kln}+\mathrm{Mnt}$ \\
BF & Eocene limestones and volcaniclastics terrains & $\mathrm{Gt}+\mathrm{Kln}+\mathrm{Ant}+\mathrm{Qz}$ \\
SGI-A & Eocene basalts & \\
\hline \hline
\end{tabular}

TABLE III. Red earths: characteristic mineral assemblages.

\begin{tabular}{lll}
\hline \hline Occurrences & \multicolumn{1}{c}{ Geological Formation } & \multicolumn{1}{c}{ Mineral assemblages } \\
\hline VTs & Eocene limestones & $\mathrm{Hem}+\mathrm{Ank}+\mathrm{Qz}+\mathrm{Ms}+\mathrm{Gt}+\mathrm{Kln}$ \\
SGI-A & Eocene basalts & $\mathrm{Hem}+\mathrm{Mnt}+\mathrm{Ant}+\mathrm{Kln}+\mathrm{Gt}$ \\
SA & Calcari Grigi dolomitizzati (Mesozoic) & $\mathrm{Hem}+\mathrm{Ank}$ \\
\hline \hline
\end{tabular}


rock. The presence of anatase associated with yellow earths represents an important marker both for the origin of goethite (basic and ultrabasic rocks) and for the archaeometric implications.

Yellow earths from the Buso del Fero mine are associated both with the Eocene volcaniclastic terrains and the upper Eocene limestones. Mineral associations reflect the level where the raw materials were collected; in this case, the assemblage goethite, kaolinite, and montmorillonite indicate a volcanic origin, whereas goethite, calcite, and quartz (detrital?) indicate the origin from the carbonates.

Red earths from the via Tirapelle mine (VTs) are clearly distinguishable from those coming from Sant'Andrea (SA) and San Giovanni Ilarione (SGI-A). In the first case, the amount of hematite is rather limited (traces) and $\alpha-\mathrm{Fe}_{2} \mathrm{O}_{3}$ occurs in mixture with goethite, imparting an orange hue to the final color; at variance, well-crystallized hematite, sometimes associated with ankerite, is characteristic for the second group of samples. Finally, poorly crystalline hematite is associated with kaolinite, montmorillonite, and anatase in the samples coming from San Giovanni Ilarione (SGI-A).

Typically, in terms of structure, the red earths analysed in this research are massive, with the notable exception of those originating from the "shark" gallery in via Tirapelle (VTs), where the stratification of the deposit is evident.

Significantly, the aforementioned considerations allow us to infer that the presence of accompanying minerals is the consequence of the geological environment and alteration processes of the mother rock and cannot be interpreted as voluntary addition during Palaeolithic pigment preparation (Gialanella et al., 2011). All together, the mineral assemblages, the degree of crystallinity of some mineralogical phases (hematite and clay minerals), the presence of diagnostic minerals (anatase), allow the classification of the collected materials in groups and subgroups to be performed, and represent an important record for on-going researches on the provenance of Late Palaeolithic archaeological ochre (see also Hradil et al., 2003). In addition, new light was shed on the composition of yellow and red earths in the Eastern sector of North Italy as no gypsum was found in the studied materials as indicated by Elias et al. (2006). This is most probably due to the fact that the materials analysed by Elias et al. come from a paint factory and would indicate a post-treatment of the raw materials.

\section{CONCLUSIONS}

The application of conventional XRPD confirmed to be a valid method for a preliminary discrimination of Fe-based natural materials as typical mineral assemblages allow the potential sources for Prehistory procurement in group and sub-groups to be classified. This is synthetically reported in Tables II and III. In addition, the goethite-hematite accompanying minerals address the geological provenance: for example, strong evidence is given for the red and yellow earths associated with basalts, where anatase and clay minerals (kaolinite and montmorillonite), as principal and/or subordinate compounds, can be considered marker-minerals in the studied area or the mineralogical association of Eocene and Mesozoic carbonate formations which is very distinctive. The degree of crystallinity of hematite is a further evidence of provenance (i.e. samples from Mesozoic carbonates and Eocene volcanic rocks). These features have great implications for provenance studies allowing the provenance area to be narrowed down. Work can be anticipated towards the complete mineralogical analysis of archaeological ochre and to establish possible correlations by further comparison with the studied raw materials. Finally, the results here obtained on the samples selected as possible material sources during the Late Palaeolithic in the Lessini Mountains (NE Italy) will be soon integrated with XRD of ochre samples also with quantitative determination of mineral phases for selected groups of geological and archaeological samples. Finally, geochemical analysis of major and trace elements on both pristine geological and archaeological samples will be developed.

\section{ACKNOWLEDGEMENTS}

We express our gratitude to Professor Norberto Masciocchi of the University of Insubria (Como, Italy) for his great support in the access to the facilities of the Department of Chemistry and for the fruitful discussion on many aspects related with the interpretation of XRD data. Particular thanks go to Dr. Federica Fontana and Dr. Marco Peresani of the University of Ferrara (Italy), Department of Humanities, Dr. Federica Gonzato of the Archaeological Office in Verona (Soprintendenza Archeologica) for their support and interest. Finally, many thanks go to Dr. Leonardo Latella of the Museum of Natural History of Verona for his great help in collecting samples from the Colombare palaeokarst cave. We are also grateful to the two anonymous reviewers who contributed with their suggestions to improve the quality of the manuscript.

Béarat, H. (1996). "Quelle est la gamme exacte des pigments Romains? Confrontation des resultats d'analyse et des textes de Vitruve et de Pline," in Roman Wall Paintings, edited by H. Béarat, M. Fuchs, M. Maggetti and D. Paunier (Institute of Mineralogy and Petrography, Fribourg, Switzerland), pp. 11-34.

Broglio, A., De Stefani, M., Gurioli, F., Pallecchi, P., Giachi, G., Higham, T., and Brock, F. (2009). "L'art aurignacien dans la décoration de la Grotte de Fumane," L'anthropologie 113, 753-761.

Cavallo, G. and Zorzin, R. (2008). "Preliminary data on the yellow ochers at the mine of Via Tirapelle in Verona (Italy)," X-Ray Spectrom. 37, 395-398.

Cavallo, G. and Zorzin, R. (2014). "Geology, petrography, mineralogy, geochemistry of natural Fe-based pigments from Verona province (Italy)," in Proc. 39th Int. Symp. on Archaeometry, edited by R. B. Scott, D. Braekmans, M. Carremans and P. Degryse (Centre for Archaeological Sciences, KU Leuven), pp. 9-15.

Cavallo, G., Cardani Vergani, R., Gianola, L., and Meregalli, A. (2012) "Archaeological, stylistic and scientific research on $11^{\text {th }}-13$ th century A.D. painted fragments from the San Giovanni Battista Church in Cevio (Switzerland)," Archaeometry 54, 294-310.

Cavallo, G., Riccardi, M. P., and Zorzin, R. (2014). "Red and yellow ocher exploitation in the Lessini mountains (Veneto, NE Italy)," in Proc. 9th Int. Symp. on Archaeological Mining History, Trento, pp. 162-169.

Chay, L. and Navrotsky, A. (1996). "Synthesis, characterization and energetics of solid solution along the dolomite-ankerite join, and implications for the stability of ordered $\mathrm{CaFe}\left(\mathrm{CO}_{3}\right)_{2}$, , Am. Mineral. 81, 1141-1147.

Dayet, L., Texier, P.-J., Daniel, F., and Porraz, G. (2013). "Ochre resources from the middle stone age sequence of Diepkloof Rock Shelter, Western Cape, South Africa," J. Archaeol. Sci. 40, 3492-3505.

Delamare, F. and Guineau, B. (2000). Colors. The Story of Pigments and Dyes (Harry N. Abrams Inc., New York), p. 159.

Elias, M., Chartier, C., Prévot, G., Garay, H., and Vignaud, C. (2006). "The colour of ochres explained by their composition," Mater. Sci. Eng. B 127, 70-80.

Federici, F. (1948). Materiali utili del suolo e del sottosuolo della provincia di Verona (La Tipografica Veronese, Verona), pp. 66-74. 
Fontana, F., Cilli, C., Cremona, M. G., Giacobini, G., Gurioli, F., Liagre, J., Malerba, G., Rocci Ris, A., Veronese, C., and Guerreschi, A. (2009).

"Recent data on the Late Epigravettian occupation at Riparo Tagliente, Monti Lessini (Grezzana, Verona): a multidisciplinary perspective," Preistoria Alpina 44, 1-6.

Gialanella, S., Belli, R., Dalmeri, G., Lonardelli, I., Mattarelli, M., Montagna, M., and Toniutti, L. (2011). "Artificial or natural origin of hematite-based red pigments in archaeological contexts: the case of Riparo Dalmeri (Trento, Italy)," Archaeometry 53, 950-962.

Helwig, K. (2007). "Iron oxide pigments" in Artists' Pigments. A Handbook of Their History and Characteristics, edited by B. H. Berrie (National Gallery of Art, Washington), Vol. 4, pp. 39-95.

Henshilwood, C. H., d'Errico, F. and Watts, I. (2009). "Engraved ochres from the Middle Stone Age levels at Blombos Cave, South Africa," J. Hum. Evol. 57, 27-47.

Hovers, E., Illani, S., Bar-Yosef, O. and Vandermeersch, B. (2003). "An early case of color symbolism. Ochre used by modern humans in Qafzeh cave," Curr. Anthropol. 44, 491-522.

Hradil, D., Grygar, T., Hradilová, J. and Bezdickka, P. (2003). "Clay and iron oxide pigments in the history of paintings," Appl. Clay Sci. 22, 223-236.

Munsell Soil Color Charts (1975). Munsell Color, Macbeth Division of Kollmorgen, Baltimore, Maryland.
Nicolis, E. (1898). "Sull'alterazione delle rocce della regione Veronese e della finitima," Regio Istit. Veneto Lett. Sci. Arti 9, 152-170.

Peresani, M., Vanhaeren, M., Quaggiotto, E., Queffelec, A. and d'Errico, F. (2013). "An ochered fossile marine shell from the Mousterian of Fumane Cave, Italy. PLoS ONE 8, e68572. doi: 10.1371/journal.pone.0068572.

Pomiès, M. P. and Menu, M. (1999). "Red Palaeolithic pigments: natural hematite or heated goethite?," Archaeometry 41, 275-285.

Pomiès, M. P., Morin, G. and Vignaud, C. (1998). "XRD study of the goethite-hematite transformation: application to the identification of heated prehistoric pigments," Eur. J. Solid State Inorg. Chem. 35, 9-25.

Salomon, H., Vignaud, C., Coquinot, Y., Beck, L., Stringer, C., Strivay, D. and d'Errico, F. (2012). "Selection and heating of colouring materials in the Mousterian level of Es-Skhul (c. 100000 years BF, Mount Carmel, Israel)," Archaeometry 54, 698-722.

Wadley, L. (2010). "Cemented ash as a receptacle of work surface for ochre powder production at Sibudu, South Africa, 58,000 years ago," J. Archaeol. Sci. 37, 2397-2406.

Whitney, D. L. and Evans, B. W. (2010). "Abbreviations for name of rockforming minerals," Am. Mineral. 95, 185-187.

Zorzin, R., Accorsi, C. A., Bandini Mazzanti, M., and Di Giuseppe, M. (1995). "Nuovi dati geologici e palinologici sul paleocarsismo delle terre coloranti dei Monti Lessini - Verona," Bollettino Museo Civico Storia Naturale Verona 19, 475-503. 